Acta Bot. Croat. 71(2), 215-227, 2012

\title{
Host range and host choice of Cuscuta species in Hungary
}

\author{
KORNÉL BARÁTH*, JÁNOS CSIKY \\ Department of Plant Systematics and Geobotany, Institute of Biology, Faculty of \\ Sciences, University of Pécs, H-7624 Pécs, Ifjuság str. 6, Hungary
}

\begin{abstract}
Extensive field studies were carried out in Hungary to get a picture of the host range and host choice of the Cuscuta species under natural conditions. We examined both parasitised and unparasitised plant species and found some aspects in which they are different. Compiling the host spectra of the various Cuscuta species based on herbaria, literature and our own observations, we can say that dodders infest at least $26 \%$ of the vascular flora of the country. In our study, the Hungarian Cuscuta species parasitised all plants that had a coverage of more than $25 \%$ in the sampling sites. We prepared a list of the most frequent host species for the parasites and revealed the importance of exclusive hosts. The results suggest that the habitat differences of the Cuscuta species can be responsible for the different host ranges. Furthermore, it was found that the reason why dodders parasitise plants from various life-forms in different proportions is not (only) the active host choice, but the characteristic features of the habitats.
\end{abstract}

Key words: Cuscuta, parasitic plant, host, habitat

\section{Introduction}

Approximately 3900 parasitic plant species are known in the world, which is more than $1 \%$ of flowering plants (NICKRENT 2002). The genus Cuscuta (dodders) comprises approximately 170 parasitic plant species widely distributed in tropical, subtropical and temperate regions (DAWSON et al. 1994). Hitherto eight Cuscuta species have been reported from Hungary: Cuscuta campestris Yuncker, C. epithymum (L.) Nath. and C. europaea L. are considered quite frequent, while $C$. lupuliformis Krock. and C. australis $\mathrm{R}$. Br. are rare parasites in the country. Cuscuta approximata Bab. is an extremely rare species, known only from one locality in South Hungary (CSIKY 2003). BARÁTH (2004) reported that $C$. epilinum Weihe probably became extinct in the country in the 1920s. C. suaveolens Ser. was only a temporary element of the Hungarian Flora about 100 years ago (BALOGH et al. 2004).

* Corresponding author, e-mail: barikori@yahoo.com

Copyright ${ }^{\circledR} 2012$ by Acta Botanica Croatica, the Faculty of Science, University of Zagreb. All rights reserved. 
Although several Cuscuta species are dangerous agricultural pests (DAWsON et al. 1994), their host range and host choice have not been sufficiently investigated. The majority of the references regarding the host spectra of dodders concern mainly cultivated plants, while most observations in natural or seminatural habitats are accidental supplements of other (taxonomical, physiological) studies on Cuscuta (GAERTNER 1950). In the past it was believed that each Cuscuta species is host-specific and able to infest only one species (cf. Dean 1934, Gaertner 1950). The names of some dodders (C. epilinum Weihe., $C$. epithymum (L.) Nath., C. polygonorum Engelm., C. cephalanti Engelm. etc.) refer to the species or genera of the host on which they were found (cf. GAERTNER 1950, ERDŐs 1971). Later, when it was realised that dodders can parasitise several species, and that even most of them have considerable host ranges, this conception changed (ENGELMANN 1843, Soó 1968). ENGELMANN (1859) and YUNCKER (1932) listed the prominent host species or genera for many dodders in their monograph and reported some Cuscuta species that are able to grow on any host(s) within reach. MiRANDE (1900) divided the Cuscuta species into two classes based on the size of their host range. The distinction of the categories can be found in recent studies as well, under the names of host-generalist and host-specialist or host-specific.

Although Engelmann (1859), HildEBRAnd (1908), THOMPSON (1911) and DEGEN (1911) examined the host species of dodders, the first extensive host index was prepared by GERTZ (1928, 1933) for C. europaea. DEAN $(1934,1935)$ systematically investigated the host range of dodders in the United States and compiled a substantial host list for $C$. gronovii Willd. ex Schult. and C. glomerata Choisy. GAERTNER (1950) realised that knowledge of the host species of dodders can be important for agronomy, plant pathology and plant taxonomy, and reviewed the literature on the host range of Cuscuta species. She compiled an extensive host list for 9 Cuscuta species based on literature and her own observations. Later ERdös (1971), KUOH and CHIANG (1989), KoJIĆ and VRBNIČANIN (2000), JAYASINGHE et al. (2004), LiAo et al. (2005), SARMA et al. (2008) and BARÁth (2004, 2009, 2010) also systematically investigated the host range of dodders, but all of them excluded unparasitised plants from consideration and did not discuss the question of host choice.

KROHN (1934) realised the importance of unparasitised plants and reported that dodders are able to grow in close proximity to several plants without parasitising them. MUSSELMAN (1986) investigated the genus Cuscuta in Virginia and stated that each species may be characterised by what it does not attack. Although some excellent laboratory experiments focused on the active host choice of some dodders (KELLY 1992, SANDERS et al. 1993, AlERS-GARCÍA 2005, RUNYON et al. 2006), our knowledge about the underlying mechanisms of the host selection under natural conditions is quite insufficient.

CsIKY et al. (2004) supposed that the Hungarian Cuscuta species are not host specific. In the cases of $C$. epithymum and $C$. campestris they found that the number of host species was positively correlated with the size of the parasites. In this study, we wanted to test the unspecific hypothesis with two other methods. Firstly, if a dodder species indiscriminately infests the surrounding plants, then the greater the species diversity is, the more species are parasitised by Cuscuta. Secondly, if a dodder is not host specific then the frequency of the host species and the frequency of their infestations must be correlated. The purpose of the present study was also to explore the qualitative and quantitative differences of the host ranges of Cuscuta species in Hungary and reveal some aspects in which the parasitised and unparasitised plant species are different. 


\section{Materials and methods}

The study was carried out on the recent Cuscuta species (C. europaea, C. campestris, C. epithymum, C. lupuliformis, C. australis, C. approximata) between 2003-2009 at 186 localities in Hungary (Fig. 1). Both parasitised and unparasitised plants were examined in the habitats using altogether 407 representative quadrats. At most two relevés were taken at the same locality, but even in these cases at least $50 \%$ of the plant species were different from each other. In the cases of the rare species (Cuscuta approximata, C. australis, C. lupuliformis) relevés were taken in the location of each known population. The percentage cover and the parasitism status were recorded for each plant species in the quadrats. Only those plants were considered hosts (parasitised plants) on which the dodder haustorium was found. In doubtful cases (often on grasses) the haustorium was cut and the penetration was checked with a magnifier or, rarely, using a stereo microscope.

Since different dodder species occur in dissimilar vegetation types in Hungary (CSIKY et al. 2004) and the size of the species also varies (BARÁTH 2004) the size of the sampling quadrats has been defined separately for each Cuscuta species in compliance with its habitat (LÁJER et al. 2007). The parasites were smaller than the sampling quadrat in every case. Altogether 116 relevés of $5 \mathrm{~m}$ x $5 \mathrm{~m}$ size were taken for C. europaea, 50 relevés of $5 \mathrm{~m}$ x $5 \mathrm{~m}$ size for Cuscuta lupuliformis, 122 relevés of $2 \mathrm{~m}$ x $2 \mathrm{~m}$ size for C. campestris, 87 relevés of $2 \mathrm{~m} \times 2 \mathrm{~m}$ size for $C$. epithymum, 29 relevés of $1 \mathrm{~m} \times 1 \mathrm{~m}$ size for $C$ australis, and 3 relevés of $1 \mathrm{~m} \times 1 \mathrm{~m}$ size in the only habitat of $C$. approximata. Despite the different sizes, the sampling quadrats faithfully represent the different habitats of the various Cuscuta species; consequently, they are comparable with each other in many aspects (HORTOBÁGYI and Simon 2000, OtYPKovÁ and CHYTRY 2006, LÁJER et al. 2007).

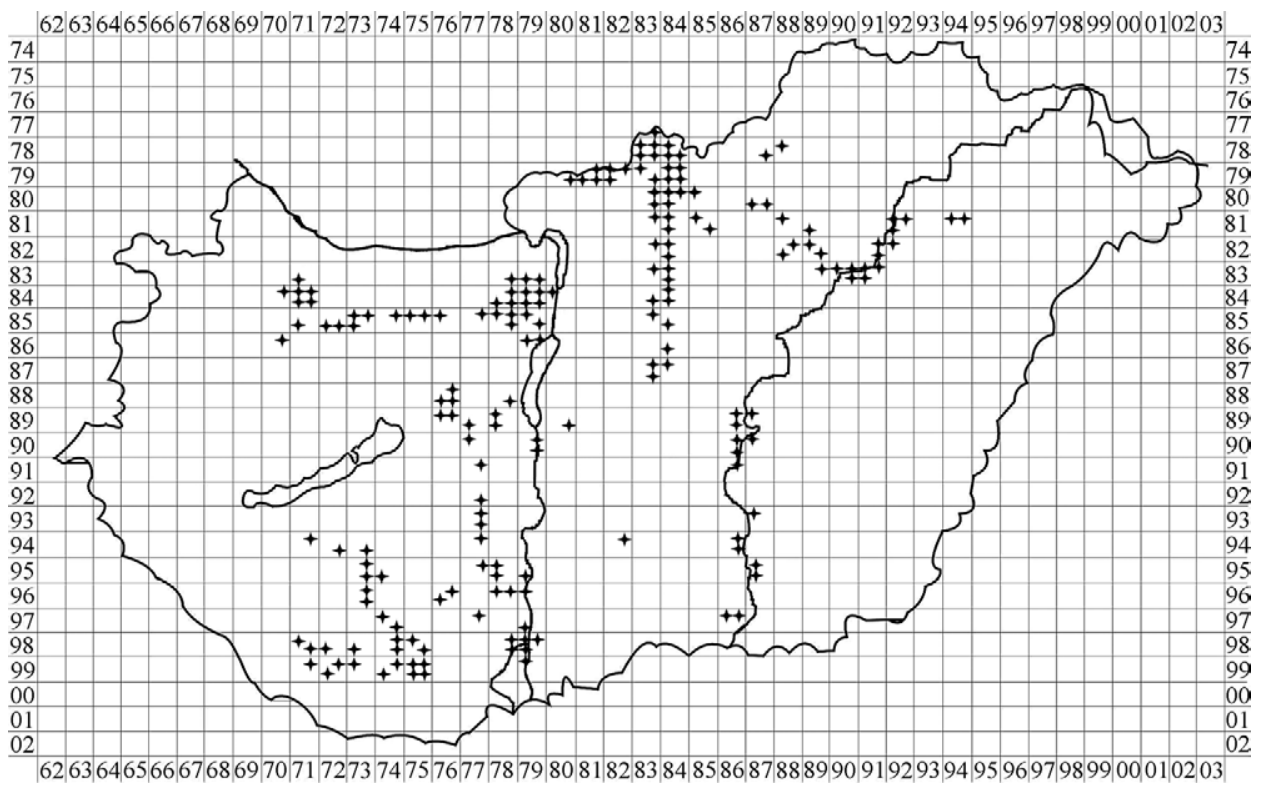

Fig. 1. Location of the sampling quadrats in Hungary according to the grid of the Central European Mapping System. 
Species were considered exclusive hosts of a given dodder if they were never found to be parasitised by other Cuscuta species. The overlapping of the host ranges of dodders was calculated as Jaccard coefficient:

$$
\frac{\mathrm{N}_{\mathrm{ab}}}{\mathrm{N}_{\mathrm{a}}+\mathrm{N}_{\mathrm{b}}} \times 100
$$

where $\mathrm{N}_{\mathrm{ab}}$ is the number of the species that were parasitised by both Cuscuta A and B. $\mathrm{N}_{\mathrm{a}}$ is the number of the host species of Cuscuta A, while $\mathrm{N}_{\mathrm{b}}$ is the same for Cuscuta B. The habitat similarities were computed in the same way based on the overlapping of all plant species of the habitats. The homogeneity between the proportions of the overlapping of the host ranges and of the overlapping of the total plants species was tested by Pearson's chi-square test. The qualitative differences between the host ranges of the various Cuscuta species were investigated according to the Raunkiaer life-form system (RAUNKIAER 1934, HoRvÁth et al. 1995). The chi-square test was used to compare the distribution of the life-forms of the host species and of the total plant species. The differences between the constancy and mean covering values of the parasitised and unparasitised plant species were investigated separately in the case of each Cuscuta species using the Brunner-Munzel test. The degree of correspondence between two variables was measured in every case by Kendall's $\tau$ rank correlation coefficient. The Brunner-Munzel test was performed with ROPstat (VARGHA 2008), while other statistical analyses (Kendall's $\tau$ and chi-square test) were performed with the PAST statistics software package (HAMMER et al. 2001). Only 3 relevés of $C$. approximata were not evaluated by statistical methods.

The host spectra of the Hungarian Cuscuta species was compiled based on our field studies, on data of several herbaria [Herbarium Carpato-Pannonicum of the Natural History Museum (BP), University of Pécs (JPU), University of Debrecen (DE), Janus Pannonius Museum (PECS), Universitatis Napocensis, Cluj-Napoca (CL)] and on the few literature sources concerning Hungary (ERDÖS 1971, CSIKY 2003). During the herbarium studies we found host plants for $C$. epilinum, but in the case of $C$. suaveolens there were not any reliable data.

\section{Results}

During the field study 459 plant species were found to be parasitised by the examined Cuscuta species. Since an additional 113 hosts were found in the course of the herbarium study and in the literature, it can be said that dodders parasitise at least 572 plant species in Hungary, which is approximately $26 \%$ of the vascular flora of the country (SIMON 2000). Cuscuta epithymum displayed the widest spectrum with 341 hosts, while C. approximata parasitised only 15 species (Tab. 1).

The host range of dodders can be characterised not only by size, but also by the proportion of the exclusive host species (Tab. 1). For example, Cuscuta europaea was found to parasitise at least 183 different plants in Hungary, but 129 of them were attacked by other dodders as well and only 54 host species were infested solely by C. europaea. The proportion of the exclusive and the total host plants reflects the degree of the peculiarity of the host ranges. This value is $29.51 \%$ for Cuscuta europaea, which is average among the Hungarian dodders. Regarding C. epithymum and C. approximata, the high proportions 
Tab. 1. The number of the host species and the proportions of the exclusive host species of the Hungarian dodders.

\begin{tabular}{lccccccc}
\hline & $\begin{array}{c}\text { Cuscuta } \\
\text { europaea }\end{array}$ & $\begin{array}{c}\text { C. } \\
\text { campestris }\end{array}$ & $\begin{array}{c}\text { C. } \\
\text { epithymum }\end{array}$ & $\begin{array}{c}\text { C. } \\
\text { lupuliformis }\end{array}$ & $\begin{array}{c}\text { C. } \\
\text { australis }\end{array}$ & $\begin{array}{c}\text { C. } \\
\text { approximata }\end{array}$ & $\begin{array}{c}\text { C. } \\
\text { epilinum }\end{array}$ \\
\hline $\begin{array}{l}\text { Number of the } \\
\text { host species (a) }\end{array}$ & 183 & 224 & 341 & 99 & 72 & 15 & 16 \\
$\begin{array}{l}\text { Number of the } \\
\text { exclusive host } \\
\text { species (b) }\end{array}$ & 54 & 68 & 199 & 13 & 12 & 7 & 2 \\
b/a x 100 (\%) & 29.51 & 30.36 & 58.36 & 13.13 & 16.67 & 46.67 & 12.50 \\
\hline
\end{tabular}

$(58.36 \%, 46.67 \%)$ of exclusive hosts are remarkable, while the host range of C. lupuliformis and C. epilinum can be characterised by only a few exclusive host species $(13.13 \%$, $12.50 \%)$.

The degree of the overlapping of the host ranges revealed both differences and similarities among the dodders (Tab. 2). The species C. europaea and C. lupuliformis had the greatest proportion of the common hosts, since 66 species were parasitised by both dodders, which is $23.40 \%$ of the total host species of the parasites.

The divergence among the species composition of the habitats (host availability) of dodders can be evaluated in the same way based on the overlapping of all plant species of the habitats. Comparing the proportions, we found that the overlapping of the host species and that of the total plant species were almost the same $\left(\chi^{2}=0.711, \mathrm{p}=0.999, \mathrm{df}=11\right)$.

The classification of the host species based on the Raunkiaer life-form system also revealed dissimilarities among the host ranges of dodders (Tab. 3). We observed also that the distribution of the life-forms was almost the same in the cases of the host species and of

Tab. 2. Overlapping of the host ranges of the Hungarian Cuscuta species.

\begin{tabular}{|c|c|c|c|c|c|c|c|}
\hline 572 & $\begin{array}{c}C . \\
\text { europaea } \\
(183)\end{array}$ & $\begin{array}{c}C . \\
\text { campestris } \\
(224)\end{array}$ & $\begin{array}{c}C . \\
\text { epithymum } \\
(341)\end{array}$ & $\begin{array}{c}C . \\
\text { lupuliformis } \\
(99)\end{array}$ & $\begin{array}{c}C . \\
\text { australis } \\
(72)\end{array}$ & $\begin{array}{c}C . \\
\text { approximata } \\
(15)\end{array}$ & $\begin{array}{c}C . \\
\text { epilinum } \\
\text { (16) }\end{array}$ \\
\hline $\begin{array}{l}\text { C. europaea } \\
\text { (183) }\end{array}$ & & 91 & 73 & 66 & 35 & 0 & 7 \\
\hline $\begin{array}{l}\text { C. campestris } \\
\text { (224) }\end{array}$ & $22.36 \%$ & & 106 & 55 & 43 & 1 & 10 \\
\hline $\begin{array}{l}\text { C. epithymum } \\
\text { (341) }\end{array}$ & $13.93 \%$ & $18.76 \%$ & & 38 & 25 & 8 & 12 \\
\hline $\begin{array}{l}\text { C. lupuliformis } \\
\text { (99) }\end{array}$ & $23.40 \%$ & $17.03 \%$ & $8.64 \%$ & & 37 & 0 & 3 \\
\hline $\begin{array}{l}\text { C. australis } \\
\text { (72) }\end{array}$ & $13.73 \%$ & $14.53 \%$ & $6.05 \%$ & $21.64 \%$ & & 0 & 2 \\
\hline $\begin{array}{l}\text { C. approximata } \\
\text { (15) }\end{array}$ & 0 & $0.418 \%$ & $2.25 \%$ & 0 & 0 & & 0 \\
\hline $\begin{array}{l}\text { C. epilinum } \\
\text { (16) }\end{array}$ & $3.52 \%$ & $4.17 \%$ & $3.27 \%$ & $1.74 \%$ & $2.27 \%$ & 0 & \\
\hline
\end{tabular}


Tab. 3. Distribution of the host plants of the Hungarian dodders based on the Raunkiaer life-form system $(\%)$.

\begin{tabular}{lccccccc}
\hline & $\begin{array}{c}\text { Cuscuta } \\
\text { europaea }\end{array}$ & $\begin{array}{c}\text { C. } \\
\text { campestris }\end{array}$ & $\begin{array}{c}\text { C. } \\
\text { epithymum }\end{array}$ & $\begin{array}{c}\text { C. } \\
\text { lupuliformis }\end{array}$ & $\begin{array}{c}\text { C. } \\
\text { australis }\end{array}$ & $\begin{array}{c}\text { C. } \\
\text { approximata }\end{array}$ & $\begin{array}{c}\text { C. } \\
\text { epilinum }\end{array}$ \\
\hline Mesophanerophytes & 5.78 & 2.14 & 1.47 & 11.63 & 3.33 & 0 & 0 \\
Microphanerophytes & 5.78 & 2.86 & 2.44 & 10.08 & 3.33 & 0 & 0 \\
Nanophanerophytes & 1.78 & 0.36 & 2.44 & 3.10 & 2.22 & 10.00 & 0 \\
Chamaephytes & 3.56 & 3.93 & 8.56 & 3.88 & 3.33 & 15.00 & 4.76 \\
Hemikryptophytes & 34.22 & 31.07 & 52.08 & 26.36 & 33.33 & 45.00 & 42.86 \\
Hemitherophytes & 13.33 & 13.21 & 7.82 & 5.43 & 6.67 & 5.00 & 19.05 \\
Therophytes & 23.56 & 37.50 & 18.83 & 19.38 & 28.89 & 10.00 & 28.57 \\
Geophytes & 7.56 & 6.07 & 5.13 & 7.75 & 4.44 & 15.00 & 4.76 \\
Epiphytes & 0.44 & 0.36 & 0.24 & 2.33 & 0 & 0 & 0 \\
Helo-. Hidrophytes & 4.00 & 2.50 & 0.98 & 10.08 & 14.44 & 0 & 0 \\
\hline
\end{tabular}

the total plant species. $\left(\chi^{2}=0.959\right.$ with $\mathrm{p}=0.999, \mathrm{df}=9$ for Cuscuta europaea, $\chi^{2}=0.228$ with $\mathrm{p}=0.999, \mathrm{df}=9$ for $C$. campestris, $\chi^{2}=0.629$ with $\mathrm{p}=0.999, \mathrm{df}=9$ for $C$. epithymum, $\chi^{2}=2.149$ with $\mathrm{p}=0.988, \mathrm{df}=9$ for $C$. lupuliformis and $\chi^{2}=0.559$ with $\mathrm{p}=0.999, \mathrm{df}=8$ for C. australis).

According to the results, Hungarian Cuscuta species parasitised all plants that had a coverage of more than $25 \%$ in the sampling sites. Moreover we found strong positive correlation between the numbers of the host species and the number of the total plant species of the sampling quadrats (Kendal $\tau_{\mathrm{b}}$ value was $\tau=0.741$ with $\mathrm{p}<0.001$ for $C$. europaea, $\tau=0.791$ with $\mathrm{p}<0.001$ for $C$. campestris, $\tau=0.746$ with $\mathrm{p}<0.001$ for $C$. epithymum, $\tau=0.623$ with $\mathrm{p}<0.001$ for $C$. lupuliformis and $\tau=0.731$ with $<0.001$ for $C$. australis).

The frequency of the species and the frequency of their infestations were also significantly correlated (Kendal $\tau_{\mathrm{b}}$ value was $\tau=0.709$ with $\mathrm{p}<0.001$ for Cuscuta europaea, $\tau=0.783$ with $\mathrm{p}<0.001$ for $C$. campestris, $\tau=0.755$ with $\mathrm{p}<0.001$ for $C$. epithymum, $\tau=0.577$ with $\mathrm{p}<0.001$ for $C$. lupuliformis and $\tau=0.814$ with $\mathrm{p}<0.001$ for $C$. australis).

A substantial difference was found between the frequency of the parasitised and unparasitised plant species in the habitat (the values of the Brunner-Munzel test were calculated $\mathrm{BM}=6.49$ with $\mathrm{p}<0.001$ for $C$. europaea, $\mathrm{BM}=7.07$ with $\mathrm{p}<0.001$ for $C$. campestris, $\mathrm{BM}=8.11$ with $\mathrm{p}<0.001$ for $C$. epithymum, $\mathrm{BM}=2.98$ with $\mathrm{p}=0.003$ for $C$. lupuliformis and $\mathrm{BM}=3.27$ with $\mathrm{p}=0.002$ for $C$. australis). Moreover, the differences between the mean cover of parasitised and unparasitised plants were also significant $(\mathrm{BM}=$ 5.73 with $\mathrm{p}<0.001$ for $C$. europaea, $\mathrm{BM}=4.51$ with $\mathrm{p}<0.001$ for $C$. campestris, $\mathrm{BM}=$ 8.98 with $\mathrm{p}<0.001$ for $C$. epithymum, $\mathrm{BM}=9.76$ with $\mathrm{p}<0.001$ for $C$. lupuliformis and $\mathrm{BM}=3.17$ with $\mathrm{p}=0.003$ for $C$. australis).

We drew up the list of the ten most frequent host plants of each Hungarian Cuscuta species based on the frequency of infestation of the host species (Tab. 4). However, it should not be forgotten that the more frequently parasitised host species are not necessarily the most preferred ones. 
Tab. 4. The most frequent host plants of the Cuscuta species in Hungary and the percentage frequency of their infestation.

\section{C. europaea}

$85.3 \%$ Urtica dioica $\mathrm{L}$.

$40.6 \%$ Elymus repens (L.) Gould.

$37.9 \%$ Humulus lupulus L.

$31.0 \%$ Rubus caesius L.

$24.1 \%$ Arrhenatherum elatius (L.) Pres1

$22.4 \%$ Galium aparine $\mathrm{L}$.

$22.4 \%$ Lactuca serriola $\mathrm{L}$.

$21.5 \%$ Sambucus ebulus L.

$21.5 \%$ Melandrium album (Mill.) Garcke

$18.9 \%$ Calystegia sepium (L.) R. BR.

\section{C. lupuliformis}

$58.0 \%$ Urtica dioica $\mathrm{L}$.

$52.0 \%$ Rubus caesius L.

$46.0 \%$ Salix triandra L.

$40.0 \%$ Calystegia sepium (L.) R. BR.

$40.0 \%$ Echinocystis lobata (Michx.) Torr. et Gray

$28.0 \%$ Elymus repens (L.) Gould.

$24.0 \%$ Lactuca serriola $\mathrm{L}$.

$20.0 \%$ Phragmites australis (Cav.) Trin. ex. Steud.

$20.0 \%$ Galium aparine L.

$16.0 \%$ Aristolochia clematitis L.

\section{C. epithymum}

$42.2 \%$ Achillea millefolium L. s.1.

$40.2 \%$ Galium verum $\mathrm{L}$.

$40.2 \%$ Arrhenatherum elatius (L.) Presl

$35.6 \%$ Plantago lanceolata L.

$33.3 \%$ Lotus corniculatus L.

$24.1 \%$ Sanguisorba minor Scop.

$22.9 \%$ Festuca rupicola Heuff.

$21.8 \%$ Teucrium chamaedrys L.

$21.8 \%$ Daucus carota L.

$20.6 \%$ Convolvulus arvensis L.

\section{C. campestris}

$68.0 \%$ Polygonum aviculare L.

$37.7 \%$ Lolium perenne L.

$36.0 \%$ Convolvulus arvensis L.

$36.0 \%$ Ambrosia artemisifolia L.

$32.8 \%$ Chenopodium album L.

$23.8 \%$ Cichorium intybus $\mathrm{L}$.

$21.3 \%$ Elymus repens (L.) Gould.

$20.4 \%$ Artemisia vulgaris L.

$19.6 \%$ Atriplex tatarica L.

18.8 \% Tripleurospermum perforatum (Mérat) Laínz

\section{C. australis}

$72.4 \%$ 2Polygonum lapathifolium L.

$72.4 \%$ Plantago major L.

$65.5 \%$ Bidens tripartita $\mathrm{L}$.

$58.6 \%$ Chenopodium ficifolium Sm.

$58.6 \%$ Myosoton aquaticum (L.) Mönch

$55.1 \%$ Chenopodium polyspermum $\mathrm{L}$.

$41.3 \%$ Potentilla supina $\mathrm{L}$.

$34.5 \%$ Alopecurus aequalis Sobol.

$34.5 \%$ Tanacetum vulgare $\mathrm{L}$.

$27.6 \%$ Polygonum aviculare L.

\section{C. approximata}

$100 \%$ Genista pilosa L.

$66.7 \%$ Rumex acetosella $\mathrm{L}$.

33.3 \% Luzula luzuloides (Lam.) Dandy et Wilm.

\section{Discussion}

In agreement with some previous studies (CSIKY et al. 2004, BARÁTH 2004), we observed a positive correlation between the number of the host species and the distribution frequency of the Cuscuta species. Drawing on six years of extensive field studies, we can say that $C$. epithymum and $C$. campestris are the most frequent Cuscuta species in Hungary and their host ranges are the widest (341 and 224 host species). Cuscuta europaea is less common and its host spectrum is also smaller (183). Cuscuta lupuliformis and C. australis are rare parasites, their host ranges comprising 99 and 72 different plants, respectively. 
Only 3 host species were found in the unique habitat of C. approximata, but another 12 parasitised plant species were recognised during the herbarium studies, so the host range of this dodder includes 15 species in Hungary. Despite the fact that $C$. epilinum had been considered a strict host specialist (PHIPPEN 1867, TótH and CAGÁŇ 2001, HAMED 2005) we found 16 host species for this dodder during the herbarium studies.

Besides the frequency, the taxonomic complexity could be the reasons for the large host range of Cuscuta epithymum. Several authors (ENGELMANN 1859, YUNCKER 1932, MiguEL and MARTín 2007 etc.) reported that this dodder is not a homogeneous species, while Babington (1843), Degen (1911), Buia (1960) and Soó (1968) separate some C. epithymum taxa as distinct species. According to the recent taxonomical books, two subspecies of C. epithymum occur in Hungary (SIMON 2000, BARÁTH and CSIKY 2009). CSIKY et al. (2004) and BARÁTH (2007) reported that the two taxa prefer different habitats. While $C$. epithymum subsp. epithymum is widespread in mesophilous meadows and pastures, $C$. epithymum subsp. kotschy (Desmoulins) Arcangeli can be found mainly in dry grasslands. Although these habitats are different from each other in many aspects, the species richness of both habitat types is high (BARÁTH 2004).

Several taxonomic books display some species or genus as frequent hosts of the Cuscuta species (SIMON 2000, KoJIĆ 1973). Although this can be useful information, the knowledge of the exclusive hosts of dodders likewise facilitates the identification. In our study, 355 (62\% of total) plant species were found to be parasitised only by one Cuscuta species. The significance of this phenomenon is that the knowledge of the majority of the parasitised plants (frequent and exclusive hosts) in a habitat is mostly enough for the identification of the species of Cuscuta itself. In the case of C. epithymum $97 \%$ of the relevés included at least one, and as many 17 exclusive host species. The ten most common hosts of this dodder are also rather particular, not frequently parasitised by others (Tab. 4). Although these proportions are somewhat lower for the other dodders, each Cuscuta species can be identified by the host species in Hungary.

The investigation of the overlapping of the host ranges revealed that the host species of Hungarian dodders are quite different. The degree of the overlapping was less than $25 \%$ in every case. The fact that $C$. europaea and $C$. lupuliformis had the greatest proportion of common hosts can be explained by the similarity of their habitats. Cuscuta europaea is widespread along streams and wet ditches, but sometimes it occurs in floodplains, which is the typical habitat of C. lupuliformis in Hungary (BARÁTH 2004, CsIKY et al. 2004). In these cases, it is observable also that they parasitise each other. Comparing the proportions of the overlapping of the host species and of the total plant species, we did not find significant differences. This indicates that the more similar the habitats of two dodders are, the higher the number of common hosts that can be found; consequently, the habitat differences of the parasites can be responsible for the different host ranges.

Classification of the host species based on the Raunkiaer life-form system revealed substantial dissimilarities among the host spectra. We found the highest proportion of phanerophytes in the case of Cuscuta lupuliformis (meso-micro-nanophanerophytes altogether is $24.81 \%$ ). This result confirms the observation that $C$. lupuliformis often parasitises trees and shrubs (RAJPUT and TAHIR 1988, RHUI-CHENG et al. 1995, Simon 2000, BARÁtH 2004, 2009, BARÁTH and CSIKY 2006). The considerable proportion of helo- and hydrophytes $(10.08 \%)$ is also a characteristic feature of the host spectrum of this dodder. The 
relatively large proportion $(52.08 \%)$ of perennials is the most important feature of the host spectrum of $C$. epithymum. In our study, this dodder parasitises dwarf shrubs more often $(8.56 \%)$ than other host species. This statement is in agreement with several field studies (Soó 1968, Strid and TAN 1991, BarÁth 2004, MeulebroucK et al. 2007). ERdöS (1971) reported that therophyte species dominate among the hosts of both Cuscuta epithymum and C. campestris. In contradiction of this observation, we found only $18.83 \%$ proportion of annuals for $C$. epithymum. The reason why his results are different from ours could be that his field studies were carried out mostly in agricultural fields and in some ruderal habitats. Although GLÜCK (1911) reported that C. epithymum var. alba infests several water- and uliginous -plants in nature, in our study, the frequency of helo- and hydrophytes infested by $C$. epithymum is very low. We found the highest helo-, hydrophyte proportion in the case of $C$. australis (14.44\%). Regarding C. campestris, our result confirms Erdős' observation (1971), as the majority of the host plants of this dodder were found to be annuals (37.50\%). We also observed that both $C$. epithymum and $C$. campestris are able to parasitise trees only in their seedling and juvenile stages. This finding corresponds with the results of JAYASINGHE et al. (2004) and MeulebroucK et al. (2007). By contrast, C. europaea was found to infest fully developed low trees, although it is not a common phenomenon either. The proportion of the hemitherophytes is remarkable in the host spectra of both $C$. europaea and C. campestris $(13.33 \%$ and $13.21 \%)$.

The correspondence between the life-form proportions of the hosts and of the total plant species confirms the explanation that dodders parasitise plants from various life-forms in different proportions not (only) because of active host choice, but also because of the characteristic features of the habitats. Cuscuta australis often infests water- and uliginousplants, because in the swamps and fens where it occurs (CSIKY et al. 2004) those plants are common. C. epithymum can be found mainly on perennial plants, because hemicryptophyte plants are the most frequent in its habitat. Cuscuta campestris infests plants mostly on the edge of roads and agricultural fields (ERDÖs 1971, CSIKY et al. 2004) and these habitats are dominated mainly by therophyte species which are the most important hosts of this parasite. We could see that $C$. lupuliformis parasitises trees and shrubs more often than other dodders, but the proportion of phanerophytes is also the highest in its habitat.

Although KROHN (1934) stated that dodders are able to grow in close proximity to several plants without parasitizing them, DEAN (1934) and YUNCKER (1921) reported that Cuscuta gronovii Willd. ex Schult infests each plant that comes into contact with it in nature. In the cases of $C$. europaea and C. campestris the same was observed by BENTHAM (1878), YUNCKER (1932) and BARÁTH (2009, 2010). In our study, Hungarian Cuscuta species parasitised all plants that had coverage of more than $25 \%$ in the sampling sites. Based on the correlation between the numbers of the hosts and of the total plants, we can say that the greater the species diversity is, the more species are parasitised by Cuscuta.

We observed that some plants were parasitised more often than others in the same type of habitat. The significant positive correlation between the frequency of the species and the frequency of their infestations proved that the more often parasitised plants are the more frequent in the habitat. The results also suggest that parasitised plants are more frequent and they occur in greater abundance in the habitat than unparasitised plants.

In conclusion, the Hungarian Cuscuta species are not host specific and are able to parasitise almost each plant that comes into contact with them. Since the habitats of Hungarian 
dodders are strongly different from each other in species diversity and composition and the host range is mostly determined by host availability, we can say that habitat differences can be responsible for the different host ranges.

\section{Acknowledgements}

We wish to express our thanks to Zoltán Bátori, Dávid Schmidt and Dániel Pifkó for assistance in field studies. Special appreciation goes to Konrád Lájer, Sándor Csete and Zoltán Csabai for help in the statistical analyses. Sincere thanks to Szilvia Kocsis and Dragica Purger for useful comments and suggestions for the manuscript.

\section{References}

Alers-GarciA, J., 2005: Active host choice and parasitism by Cuscuta gronovii: its effects on host individuals, population and mutualistic interaction. $\mathrm{PhD}$ Thesis, Indiana University, Bloomington.

Babington, C. C., 1843: Note on a supposed New British Cuscuta. The Phytologist 1, 467.

BAlOGH, L., DANCZA, I., KIRÁLY, G., 2004: Actual list of neophytes in Hungary, and their classification according their invasiveness (in Hungarian). In: MiHÁLY, B., BotTADukÁt, Z. (eds.), Invasive plants - Biological invasions in Hungary, 61-92. Természetbúvár Alapítvány Kiadó, Budapest.

BARÁTH, K., 2004: Host specificity, distribution and taxonomy of the Hungarian Cuscuta species (in Hungarian). BSc Thesis, University of Pécs, Pécs.

BArÁth, K., Csiky, J., 2006: Dodders (Cuscuta). In: Ujhelyi, P., Molnár, V. A. (eds.), Life encyclopedia, plants and fungi of the Carpathian basin, 428-430. Kossuth publisher, Budapest.

BARÁTH, K., 2007: Host specificity, distribution and taxonomy of the Hungarian Cuscuta species (in Hungarian). In: SALAMON-AlBERT, É. (ed.), Plant research at the University of Pécs, 52-56. University of Pécs, Pécs.

BARÁth, K., 2009: The genus Cuscuta (Convolvulaceae) in the Andaman Islands with a new record. Acta Botanica Hungarica 51, 261-272.

BARÁTH, K., CsIKY, J., 2009: Cuscutaceae. In: KIRÁly, G. (ed.), New Hungarian herbal - the vascular plants of Hungary, identification key (in Hungarian), 333-335. Aggtelek National Park Directorate, Aggtelek.

BARÁth, K., 2010: The Cuscuta subgenus Grammica (Convolvulaceae) on the Palni hills with a new record. Acta Botanica Hungarica 52, 227-238.

Bentham, G., 1878: Handbook of the British flora. Reeve and Co., London.

BuiA, A., 1960: Cuscutaceae Dumort. In: SĂvulescu, T. (ed.), Flora of People's Republic of Romania, 7, 155-183. Editura Academiei Republici Populare Romine, Bucharest.

CsIKY, J., 2003: Cuscuta approximata Babington in Hungary (Cuscutaceae Dumort.). Kitaibelia 8, 75-80.

CSIKY, J., BARÁth, K., LÁJer, K., 2004: Cuscuta species in Hungary. Journal of Plant Diseases and Protection 19, 201-208. 
Dawson, J., Musselman, L. J., Dorr, I., Wolswinkel, P., 1994: Biology and control of Cuscuta. Review of Weed Science 6, 265-317.

DeAn, H. L., 1934: Host plants of Cuscuta gronovii. Rhodora 36, 372-375.

DeAn, H. L., 1935: Host plants of Cuscuta glomerata. Proceedings of the Iowa Academy of Science 42, 45-57.

Degen, Á., 1911: Studies on dodders (in Hungarian). Kísérletügyi Közlemények 14, 1-76.

Engelmann, G., 1843: Corrections and additions to the monography of North American Cuscutineae. American Journal of Science and Arts 45, 73-77.

Engelmann, G., 1859: Systematic arrangement of the species of the genus Cuscuta, with critical remarks on old species and descriptions of new ones. Transactions of the Academy of Sciences of St. Louis 1, 453-523.

ERdös, P., 1971: Host plants of Cuscuta trifolii Bab. and Cuscuta campestris Yunck. Botanikai Közlemények 58, 145-151.

GAERTNER, E. E., 1950: Studies of seed germination, seed identification, and host relationships in dodders, Cuscuta spp. Memoirs of the Cornell University Agricultural Experiment Station 294, 3-56.

GertZ, O., 1928: Hosts of C. europaea (in Swedish). Botaniska Notiser 1928, 320-322.

Gertz, O. 1933: Additional host species for C. europaea (in Swedish). Botaniska Notiser 1933, 505-508.

GLÜCK, H., 1911: Biologische und morphologische Untersuchungen über Wasser- und Sumpfgewächse. Die Uterflora 3, Jena.

HAMED, K. A., 2005: Pollen and seed characters of certain Cuscuta species growing in Egypt with a reference to a taxonomic treatment of the genus. International Journal of Agriculture and Biology 7, 325-332.

Hammer, O., Harper, D. A. T., Ryan, P. D., 2001: PAST: Paleontological statistics software package for education and data analysis. Palaeontologia Electronica 4, 9.

Hildebrand, F. R., 1908: Über die Wirtspflanzen von Cuscuta europaea und Cuscuta lupuliformis. Beihefte zum Botanisches Zentralblatt 24, 91-95.

HortobÁgyi, T., Simon, T., 2000: Geobotany, syntaxonomy and plant ecology (in Hungarian). Nemzeti Tankönyv kiadó, Budapest.

Horváth, F., Dobolyi, K., Karas, L., LöKös, L., Morschhauser, T., Szerdahelyi, T., 1995: Hungarian Flora Database 1.2. List of taxa and relevant attributes. Flora workgroup - Institute of Ecology and Botany of the Hungarian Academy of Sciences and Department of Botany, Hungarian Natural History, Vácrátót - Budapest.

Jayasinghe, C., Wijesundara, D. S. A., Tennakoon, K. U., Marambe, B., 2004: Cuscuta species in the lowlands of Sri Lanka, their host range and host-parasite association. Tropical Agricultural Research 16, 223-241.

Kelly, C. K., 1992: Resource choice in Cuscuta europaea. Proceedings of the National Academy of Sciences 89, 12194-12197.

KoJIĆ, M., 1973: Cuscuta. In: Josifović, M. (ed.), Flora of Republic of Serbia (in Serbian), 593-607. SANU, Belgrade. 
KoJić, M., VRBniČAnIN, S., 2000: Parasitic weeds - main characteristics, taxonomy, biodiversity and distribution. Dodders (Cuscuta L.) (in Serbian). Acta Biologica Jugoslavica Ser. G: Acta Herbologica 9, 21-28.

KroHn, V., 1934: Kurzer Bericht über Cuscuta halophyta Fries. Phytopathologische Zeitschrift 7, 505-514.

Kuoh, C. S., Chiang, S. H. T., 1989: Host plants and the haustorium of Cuscuta japonica Choisy var. formosa (Hay.) Yunker (Convolvulaceae). Taiwania 34, 11-27.

LÁJer, K., Botta-Dukát, Z., Csiky, J., Horváth, F., Szmorad, F., Bagi, I., Dobolyi, K., Hahn, I., KovÁcs, J. A., RÉDEI, T., 2007: Hungarian phytocoenological database (CoenoDatRef): sampling methodology, nomenclature and actual stage. Annali di Botanica 7, 197-210.

Liao, G. I., Chen, M. Y., Kuoh, C. S., 2005: Distribution and Host Range of Cuscuta in Taiwan, Kinmen and Matsu, with Special Reference to Host Preference of $C$. japonica var. formosana. BioFormosa 40, 17-24.

Meulebrouck, K., Ameloot, E., Verheyen, K., Hermy, M., 2007: Local and regional factors affecting the distribution of the endangered holoparasite Cuscuta epithymum in heathlands. Biological Conservation 140, 8-18.

Miguel, A. G., Martín, M. P., 2007: Phylogeny of Cuscuta subgenus Cuscuta (Convolvulaceae) based on nrDNA ITS and chloroplast trnL intron sequences. Systematic Botany 32, 899-916.

MirandE, M., 1900: Recherches physiologiques et anatomiques sur les Cuscutacées (thèse de doctorat ès sciences) Bulletin Scientifique de la France et de la Belgique 34, 1-280.

Musselman, J. L., 1986: The genus Cuscuta in Virginia. Castanea 51, 188-196.

Nickrent, D. L., 2002: Parasitic plants of the world. In: López-SÁez, J. A., Catalán, P., SÁEZ, L. (eds.), Parasitic plants of the Iberian Peninsula and Balearic Islands, 7-27. Mundi-Prensa, Madrid.

Otypková, Z., Chytry, M., 2006: Effects of plot size on the ordination of vegetation samples. Journal of Vegetation Science 17, 465-472.

PhipPen, G. D., 1867: Parasitic plants. The American Naturalist 1, 188-196.

Rajput, M. T. M., TAhiR, S. S., 1988: Cuscutaceae. Flora of Pakistan 189, 1-24.

RAUNKIAER, C., 1934: The life forms of plants and statistical plant geography. Clarendon Press, Oxford.

Rhui-Cheng, F., Musselman, L. J., Plitmann, U., 1995: Cuscuta. In: Zheng-Yi, W., RAVEN, P. H. (eds.), Flora of China, 16 (Gentianaceae through Boraginaceae), 322-325. Science Press and St. Louis, Beijing.

Runyon, J. B., Mescher, M. C., De Moraes, C. M., 2006: Volatile chemical cues guide host location and host selection by parasitic plants. Science 313, 1964-1967.

Sarma, H., Sarma, C. M., Bhattacharjya, D. K., 2008: Host Specificity of Cuscuta reflexa Roxb. in the Manas Biosphere Reserve, Indo-Burma Hotspot. International Journal of Plant Production 2, 175-180.

Sanders, I. R., Koide, R. T., Shumway, D. L., 1993: Mycorrhizal stimulation of plant parasitism. Canadian Journal of Botany 71, 1143-1146. 
SimON, T., 2000: Key to the vascular flora of Hungary (in Hungarian). Nemzeti tankönyvkiadó, Budapest.

Soó, R., 1968: Synopsis systematico-geobotanica florae vegetationisque Hungariae, 3 (in Hungarian). Akadémia kiadó, Budapest.

STRID, A., TAN, K., 1991: Mountain flora of Greece. University Press, Edinburgh.

Thompson, H. S., 1911: Cuscuta on limestone polypody. Journal of Botany, British and Foreign 49, 369.

TóTH, P., CAGÁŇ, L., 2001: Spread of dodder (Cuscuta spp.) in the agroecosystems of Slovakia: is it an emerging problem? Proceedings of the International Scientific Conference on the occasion of the 55th anniversary of the Slovak Agricultural University, Nitra, 117-120.

VARGHA, A., 2008: New possibilities with new methods: What does ROPstat offer to the research in psychology? (in Hungarian). Pszichológia 28, 81-103.

YUNCKER, T. G., 1921: Notes on our Indiana dodders. Proceedings of Indiana Academy of Science 1919, 157-163

Yuncker, T. G., 1932: The genus Cuscuta. Memoirs of the Torrey Botanical Club 18, 113-331. 